\title{
Democratic Participation and the Separation of Powers
}

\author{
Henk Botha
}

This essay asks whether and to what extent Dominik Steiger's proposed use of the separation-of-powers principle to mediate the tension between individual and collective self-determination, can shed light on the South African Constitutional Court's jurisprudence on democratic participation. It considers this question within two different contexts, namely public participation in the law-making process, and engagement with residents who are about to be evicted from their homes. It argues that, in the South African context, this model needs to be supplemented by a keen awareness of the ways in which unequal power relations affect the capacity of the poor and marginalised to participate on an equal footing. The boundary between individual and collective participation must be drawn and redrawn in a manner that is sensitive to the effects of deep-seated structural inequality on the capacity of voices and viewpoints to be heard.

\section{A. Introduction}

In his essay, ${ }_{1}^{1}$ Dominik Steiger shows that there are different values and principles underlying the demand, in constitutional and administrative law, for participation in state decision making. These principles are often in tension: the rule of law or Rechtsstaat principle, ${ }^{2}$ together with individual

1 Dominik Steiger, Gewaltenteilung als Mittel zur Konzeptualisierung von Partizipation, in: Henk Botha / Nils Schaks / Dominik Steiger (eds.), Das Ende des repräsentativen Staates? Demokratie am Scheideweg / The End of the Representative State? Democracy at the Crossroads, Nomos 2016, p. 359.

2 In this essay, I refer mostly to the 'rule of law', since that is the term used in s 1(c) of the Constitution of the Republic of South Africa, 1996 (hereinafter 'the Constitution'). However, I use the term in a general sense which is not specific to the Anglo-American legal tradition, and which does not confine its meaning to the classical, Diceyan understanding, which is in many respects inappropriate for trying to understand the rule of law under a supreme, value-based constitution. See generally Frank Michelman, The Rule of Law, Legality and the Supremacy of the Constitu- 
rights, pulls in the direction of individual forms of participation, whereas the principle of democracy tends to favour broader, more public forms of participation. These two principles also have different implications for the following two questions: what participation must, at a minimum, entail; and what the legal consequences of non-compliance are.

Steiger argues that an external principle is needed to resolve these tensions. This he finds in the doctrine of separation of powers. The judicial function is identified, above all, with the Rechtsstaat principle and fundamental rights. Judges' decision-making power is tightly circumscribed by legal rules, is restricted to disputes that originated in the past and generally binds only the parties to the dispute. Rights of participation in the judicial process are therefore limited to the individuals and stakeholders concerned. The legislative function, on the other hand, is closely associated with the principle of democracy. A democratically elected legislature is bound only by the Constitution, and makes decisions that are oriented towards the future and that have general application. Rights of participation in the legislative process should, accordingly, be extended to the general public.

The executive authority and state administration fall somewhere in between. In some cases, executive decision making approximates the legislative function. For instance, where the executive makes policy decisions, its decision making powers are relatively unconstrained, are oriented to the future and concern the general public. Where, on the other hand, an official takes decisions in terms of an authorising law, the nature of his/her discretion is closer to that of the judiciary, as it is narrowly circumscribed and binds only the individual(s) concerned. To determine who may participate and to what extent, it is therefore necessary to locate the executive or administrative decision on a sliding scale. Where it comes close to an exercise of legislative power, the circle of those entitled to participate must be extended to a diversity of stakeholders, or even the general public. Where, on the other hand, it comes closer to an exercise of judicial power, only the individuals concerned need to be involved in the decision making process.

That this model strikes a chord with the thinking of South African lawyers and legislators is clear from the distinction made in the Promotion

tion, in: Stuart Woolman / Michael Bishop / Jason Brickhill (eds.), Constitutional

Law of South Africa, $2^{\text {nd }}$ edition, Cape Town 2005, ch. 11. 
of Administrative Justice Act 3 of 2000 (PAJA) between the procedural fairness of administrative action affecting any person and the procedural fairness of administrative action affecting the public. Section 3 of PAJA guarantees the right of any person, whose rights or legitimate interests are affected, to procedurally fair administrative action. This includes the right to be given adequate notice of the nature and purpose of the action and a reasonable opportunity to make representations. This right clearly vests in individuals who are personally affected by an administrative decision. In Steiger's terminology, it relates to decisions that are similar to judicial pronouncements, and are guided above all by the Rechtsstaat principle and fundamental rights safeguarding an individual sphere of self-determination. Section 4 , by contrast, deals with administrative action affecting the public. In such cases, the administrator has a choice to hold a public inquiry, to follow a notice and comment procedure, or to implement both these procedures. These decisions are, presumably, closer to legislative enactments, in that they involve a wider discretion, are oriented to the future and affect a broader public. Here, the principle of democracy - or collective self-determination - comes into its own, and the involvement of a broader circle of participants is envisioned. ${ }^{3}$ It must, however, be pointed out that these are not watertight categories, and that one and the same decision can affect the rights of individuals and of the general public, in which case sections 3 and 4 must both be complied with. ${ }^{4}$

How helpful is a separation-of-powers-based conceptualisation of participation in attempting to come to terms with the 'participatory turn' 5 in post-apartheid law, in general, and in the Constitutional Court's jurisprudence, in particular? Can it guide our thinking on questions relating to who may participate, the legal consequences of the state's failure to comply with its duty to facilitate participation, and the extent to which the

3 See Karthy Govender, An Assessment of Section 4 of the Promotion of Administrative Justice Act 2000 as a Means of Advancing Participatory Democracy in South Africa, SA Public Law 18 (2003), p. 408, who states that section 3 of PAJA deals with 'individual adjudication and determination', while section 4 applies to 'decisions of a general or legislative nature'; Minister of Health v New Clicks SA (Pty) Ltd 2006 (2) SA 311 (CC); 2006 (1) BCLR 1 (CC), paras 153-154, 177.

4 Cora Hoexter, Administrative Law in South Africa, $2^{\text {nd }}$ edition, Cape Town 2012 , p. 411.

5 Wessel le Roux, The Democratic Turn and (the Limits of) Constitutional Patriotism after the Truth and Reconciliation Commission: Albutt $v$ CSVR, Constitutional Court Review 4 (2011), p. 51. 
needs and wishes of the public, as expressed through participation, must be factored into decision-making?

In this essay, I consider these questions within the context of two areas in which the state is required to facilitate public participation. The first deals with participation in the law-making process, while the second relates to the rights of participation of individuals and households who are about to be evicted from their homes. Although there are many other areas in which the state is required to engage with the public, whether in terms of the Constitution, ${ }^{6}$ legislation ${ }^{7}$ or case law, ${ }^{8}$ I will focus mainly on the above two categories. This is not only because the courts have traversed these two issues in some detail, but also because they represent different points on the separation-of-powers sliding scale. The first concerns the exercise of original legislative power by elected legislative assemblies that are bound only by the Constitution and charged with the making of laws that are prospective and general in application. By contrast, the second involves the exercise of a discretion which is closely bounded by applicable legislation, and which applies to particular individuals and households. ${ }^{9}$

6 For example, the Constitution guarantees the right to participate in the activities of a political party (s 19(1)(b)); states that one of the objects of local government is to encourage the involvement of communities and community organisations in local government matters (s 152(1)(e)); and decrees that the public administration must be governed by the principle that people's needs must be responded to, and that the public must be encouraged to participate in policy-making (s 195(1)(e)).

7 For example, the Local Government: Municipal Systems Act 32 of 2000 enjoins local government to develop a culture of democratic participation (s 16) and to establish appropriate mechanisms, processes and procedures to enable community participation in the affairs of the municipality (s 17). It also makes for community participation in the drafting of a municipality's integrated development plan (s 29(1)(b) (ii)). The Local Government: Municipal Structures Act 117 of 1998 provides for the establishment of ward committees which must enhance participatory democracy in local government (s 72(3)).

8 See, for example, Albutt $v$ Centre for the Study of Violence and Reconciliation 2010 (3) SA 293 (CC); 2010 (5) BCLR 391 (CC).

9 Both concern formal spaces, which are framed by the state and where members of the public participate at the state's invitation. However, that is not to suggest that these are the only spaces that are relevant to participatory democracy in South Africa. See Susan Booysen, Public Participation in Democratic South Africa: From Popular Mobilisation to Structured Co-Optation and Protest, Politeia 28 (2009) 7-18 for a typology of public participation in South Africa which includes both bottomup and top-down initiatives. 


\section{B. Public participation in the legislative process}

Sections 59(1)(a), 72(1)(a) and 118(1)(a) of the Constitution provide that the National Assembly, National Council of Provinces and provincial legislatures respectively must facilitate public involvement in their legislative and other processes. In the Doctors for Life ${ }^{10}$ and Matatiele ${ }^{11}$ judgments, the majority of the Court held that these provisions impose an enforceable obligation on legislatures to facilitate public participation, and that a failure on the part of the legislature to act reasonably in discharging this duty leads to the invalidity of the legislation in question. What is reasonable will depend on a range of factors, including the nature and importance of the legislation, its impact on the public, its urgency, and Parliament's own views on what would be appropriate. ${ }^{12}$

The right to participate in the law-making process accrues to a broad public consisting, in the case of Acts of Parliament, of all citizens or, possibly, all residents. ${ }^{13}$ In terms of Steiger's framework, democracy, rather than the rule of law or fundamental rights, is the guiding principle, and the question in any given case would be whether the public, rather than certain individuals, was afforded a reasonable opportunity to participate. This is, however, subject to two important qualifications. First, Parliament is under a positive obligation to ensure that citizens have an effective opportunity to participate in the legislative process. ${ }^{14}$ Depending on the nature and importance of the legislation and its impact on the public, Parliament's fail-

10 Doctors for Life International v Speaker of the National Assembly 2006 (6) SA 416 (CC); 2006 (12) BCLR 1399 (CC).

11 Matatiele Municipality v President of the Republic of South Africa (2) 2007 (1) BCLR 47 (CC).

12 Doctors for Life, note 10, paras 118-129, 145-146.

13 Even though s 19 of the Constitution, which guarantees political rights, refers only to citizens, it is doubtful whether residents who do not have South African citizenship, can be excluded altogether from rights of democratic participation. Other constitutional guarantees, such as human dignity (s 10), which accrue to all persons, can presumably be invoked to challenge certain nationality-based exclusions from rights of political participation. See Wessel le Roux, Representative Democracy, Migration and Residence Based Voting Rights in Post-Apartheid South Africa and Post-Unification Germany (1990-2015) in: Henk Botha / Nils Schaks / Dominik Steiger (eds.), Das Ende des repräsentativen Staates? Demokratie am Scheideweg / The End of the Representative State? Democracy at the Crossroads, Nomos 2016, p. 173.

14 Doctors for Life, note 10, paras 130-134. 
ure to facilitate the involvement of the poor, the vulnerable or those living in remote areas (e.g. where public hearings were held only in big cities) could result in the invalidity of the legislation in question. Second, the Constitutional Court insisted in the Matatiele judgment that, where a law is likely to have a particular impact on a discrete and identifiable group or community, the legislature can be expected to "ensure that the potentially affected section of the population is given a reasonable opportunity to have a say'. ${ }^{15}$ The Court held that the KwaZulu-Natal provincial legislature should have afforded the people of Matatiele a reasonable opportunity to engage with it on the area's transfer from KwaZulu-Natal to the province of the Eastern Cape. This creates a more onerous obligation on the legislature in relation to discrete sections of the population that are directly affected by the law in question, without affecting the basic principle that all members of the public must be afforded the right to participate. ${ }^{16}$

The reasoning in Doctors for Life and Matatiele II seems particularly promising when viewed from the perspective of the representation of the poor and other vulnerable groups. They emphasise the agency and voice of those traditionally excluded from democratic citizenship, and require the state to take positive steps to secure conditions under which citizens including the poor and marginalised - can exercise rights of democratic participation. They also rest upon a conception of political equality which is inconsistent with the capacity of the wealthy and powerful to pass off their private interests as the public interest or to insulate their power and influence from mechanisms designed to promote democratic accountability. ${ }^{17}$ However, subsequent judgments serve as a reminder of the challenges facing attempts to promote the state's responsiveness through public participation. On three occasions, the Court had to decide cases dealing with the duty of provincial legislatures to facilitate public involvement in relation to constitutional amendments which affect the boundaries of a

15 Matatiele, note 11, para 68.

16 In Poverty Alleviation Network v President of the Republic of South Africa 2010 (6) BCLR 520 (CC) para 53, the Court made it clear that its earlier statement in Matatiele must not be taken to mean that an identifiable and discrete group must be allowed to participate 'at the exclusion of all others'.

17 Doctors for Life, note 10, para 115 (public participation, 'because of its open and public character acts as a counterweight to secret lobbying and influence peddling. Participatory democracy is of special importance to those who are relatively disempowered in a country like ours where great disparities of wealth and influence exist'). 
specific province or provinces. In all three cases, the relevant provincial legislatures had held public hearings, as dictated by the earlier holding in Matatiele. At these public hearings, the communities who were about to be relocated from one province to another expressed their opposition to the proposed move, but the relevant provincial legislatures nevertheless proceeded to approve the amendments. Not surprisingly, this gave rise to accusations that the legislatures were not serious about the consultation process and did not give the communities' views proper consideration.

These constitutional challenges were all dismissed. In the Merafong case, where the Gauteng provincial legislature initially opposed the incorporation of the area in question into the North West province but later reversed its position, the majority of the Court held that, while the legislature was constitutionally obliged to be open to the views expressed by the public, it was not bound by them, ${ }^{18}$ and that there was nothing to suggest that the public meeting was a mere charade or that the incorporation of Merafong into North West was always a done deal. In Poverty Alleviation Network, the Court similarly rejected the contention that the legislators were instructed by the ruling party to vote for the amendment and that the decision was predetermined. ${ }^{19}$ And in Moutse, the Court dismissed the argument that the representations made during the public hearings were not fully and faithfully relayed to the provincial legislature. Despite the fact that the Court described the report of the portfolio committee which served before the legislature as 'skeletal', it held that it was not entitled to 'pronounce on the adequacy of the information at the disposal of a deliberative body such as the legislature before it makes a decision' ${ }^{20}$

These cases raise important questions about the courts' role in testing whether the state has complied with its duty to facilitate public participation. Can judges only test whether there has been formal compliance? Or

18 'Government certainly can be expected to be responsive to the needs and wishes of minorities or interest groups, but our constitutional system of government would not be able to function if the Legislature were bound by these views. The public participation in the legislative process, which the Constitution envisages, is supposed to supplement and enhance the democratic nature of general elections and majority rule, not to conflict with or even overrule or veto them'. Merafong Demarcation Forum v President of the Republic of South Africa 2008 (5) SA 171 (CC); 2008 (10) BCLR 968 (CC), para 50.

19 Poverty Alleviation Network, note 16, para 73.

20 Moutse Demarcation Forum v President of the RSA 2011 (11) BCLR 1158 (CC), para 80. 
can they go further, by questioning whether the state has actually considered public submissions, rather than simply going through the motions of public consultation? If the latter, on the basis of what evidence and on what legal grounds can they invalidate laws due to deficiencies in the public participation process?

The constitutional challenges in these cases were based not only on the public involvement requirement, but also on the alleged lack of rationality of the legislatures' decisions. In Merafong, it was argued that the Gauteng Provincial Legislature had no rational basis for its decision to reverse its mandate and to vote in favour of the constitutional amendment incorporating Merafong into the North West. Similarly, it was contended in Poverty Alleviation Network that the approval by the KwaZulu-Natal provincial legislature of an amendment which would incorporate Matatiele into the Eastern Cape, in spite of the Matatiele community's clearly expressed opposition to the move, was arbitrary. The Court rejected these submissions. It held that it was not its task to second-guess the legislature's choices, but that it could only enquire whether the decisions to relocate these areas were rationally linked to a legitimate government objective. ${ }^{21}$ Moreover, it was not to enquire into the individual motives of legislators. ${ }^{22}$ In both cases, the Court found that the relocation of the areas was rationally connected to the abolition of cross-boundary municipalities.

The Court's reasoning does not bode well for the future of rationality review as a means of questioning whether the state considered public submissions rationally and in good faith. Even when measured against the Court's usual caution in applying the rationality standard, which is a far less exacting standard than reasonableness, ${ }^{23}$ its application of the rationality test in the participation cases appears deferential. Apart from the Court's unwillingness to consider the legislative motive and the very broad latitude it leaves to the legislature, it also does not inquire into the rationality of the procedures used by the legislature in reaching a decision. In Poverty Alleviation Network the Court expressly uncoupled rationality from the procedural requirements relating to participation, and insisted

21 Merafong, note 18, para 114.

22 Poverty Alleviation Network, note 16, para 73.

23 See New National Party of South Africa $v$ The Government of the Republic of South Africa 1999 (3) SA 191 (CC); 1999 (5) BCLR 489 (CC), para 24; Pharmaceutical Manufacturers Association of SA in re: the Ex Parte Application of the President of the RSA 2000 (2) SA 674 (CC); 2000 (3) BCLR 241 (CC), para 90. 
that rationality review concerns itself with outcomes, not procedures. ${ }^{24}$ This appears incongruent with the judgments in the Albut ${ }^{25}$ and Democratic Alliance ${ }^{26}$ cases, in which the rationality requirement was extended to the way in which decisions were reached. In Albutt, the failure to provide victims an opportunity to participate in proceedings concerning the pardoning of political offenders, was held to be arbitrary, while in Democratic Alliance, the President's failure to give consideration to the findings of two commissions, which cast doubt over the honesty and credibility of the person appointed to the position of National Director of Public Prosecutions, was similarly found to be irrational.

The effectiveness of judicial scrutiny of compliance with the public involvement requirement thus appears to be undermined by the strictness of the division between the principles of the rule of law (from which the rationality requirement is derived) and democracy. Democratic procedures and the rational link that is required, in terms of the rule of law, between means and ends, are treated as separate, rather than partially overlapping inquiries. This precludes the Court from asking whether a legislative decision that is directly at odds with the submissions received from the public, was reached in terms of a rational procedure which duly considered the public's inputs. According to some commentators, this is understandable in view of the Court's precarious institutional position and/or the respect that is due to the democratically elected legislature. ${ }^{27}$ However, others have argued that judgments like Merafong and Poverty Alleviation Network undermine the transformative potential of the participatory turn in the Court's jurisprudence. These judgments are criticised for allowing the state to evade its responsibility to listen to the views of citizens, ${ }^{28}$ or for

24 Poverty Alleviation Network, note 16, para 68.

25 Albutt, note 8, para 50.

26 Democratic Alliance v President of the RSA 2013 (1) SA 248 (CC); 2012 (12) BCLR 1297 (CC), para 34-40.

27 Alistair Price, Rationality Review of Legislation and Executive Decisions: Poverty Alleviation Network and Albutt, South African Law Journal, 127 (2010), pp. 588-590.

28 Michael Bishop, Vampire or Prince? The Listening Constitution and Merafong Demarcation Forum \& Others $v$ President of the Republic of South Africa \& Others, Constitutional Court Review 2 (2009), p. 313. 
resting upon a misconception of the Court's role in a dominant party democracy. $^{29}$

\section{Meaningful engagement in eviction cases}

Forced removals and evictions provided apartheid politicians and bureaucrats with a powerful mechanism to achieve racial segregation and domination. The Constitution disavows reliance on the harsh measures of the past and provides, in s 26(3), that individuals may not be evicted from their homes without an order of court after considering all the relevant circumstances, and that legislation may not allow arbitrary evictions. Those whose eviction is sought must be treated as 'individual bearer[s] of rights entitled to respect for [their] dignity', and not as 'faceless and anonymous squatters automatically to be expelled as obnoxious social nuisances' ${ }^{30} \mathrm{In}$ line with this approach, the Constitutional Court has held that the state has a duty to engage meaningfully with occupiers before evicting them from their homes. ${ }^{31}$ It derived this duty not only from s 26(3), read with the constitutional right and value of human dignity, ${ }^{32}$ but also from the state's obligation, in terms of s 26(2) of the Constitution, to take reasonable measures to provide access to housing. ${ }^{33}$ Such engagement serves to inform the residents of the purpose of the government programme and the details of the envisaged relocation. It also assists the parties in determining the likely consequences of the eviction and how they can be alleviated. ${ }^{34}$

The rule of law and the dignity of those about to be evicted thus appear to be the overriding principles guiding participation in these cases. Ac-

29 Sujit Choudhry, 'He Had a Mandate': The South African Constitutional Court and the African National Congress in a Dominant Party Democracy, Constitutional Court Review, 2 (2009), pp. 61-67.

30 Port Elizabeth Municipality v Various Occupiers 2005 (1) SA 217 (CC); 2004 (12) BCLR 1268 (CC) para 41.

31 Occupiers of 51 Olivia Road, Berea Township v City of Johannesburg 2008 (5) BCLR 475 (CC); Residents of Joe Slovo Community, Western Cape v Thubelisha Homes 2009 (9) BCLR 847 (CC); 2010 (3) SA 454 (CC); Abahlali Basemjondolo Movement SA v Premier of the Province of Kwazulu-Natal 2010 (2) BCLR 99 (CC).

32 Olivia Road, note 31, paras 10, 16.

33 Olivia Road, note 31, paras 17-18.

34 Residents of Joe Slovo Community, note 31, para 242. 
cordingly, the state must engage with the individuals and households affected, rather than with the general public. In its interim order in the Olivia Road case, the Court ordered the city of Johannesburg to engage meaningfully with the more than 400 occupiers of the buildings that were deemed to be unsuitable for human habitation. ${ }^{35}$ And in the Joe Slovo case, in which the Court ordered the eviction of residents from an informal settlement in order to enable the state to build formal housing, it required the state to engage with affected residents in respect of each relocation. ${ }^{36}$

The principle that the state must engage with the individuals and households concerned, is subject to some qualifications. In the first place, the unequal bargaining power of the parties to the engagement could pose problems. In the Olivia Road judgment, the Constitutional Court, recognising the vulnerability of people about to be evicted, stated that '[c]ivil society organisations that support the people's claims should preferably facilitate the engagement process in every possible way'. ${ }^{37}$ Such organisations will often have knowledge of the difficulties facing uprooted communities, and are likely to inject a stronger public-interest dimension into the deliberations. The court may also lay down certain minimum requirements relating, for instance, to the alternative accommodation to be provided.

A second problem pertains to the relationship between the particularity of individual cases and litigants and the collective and systemic dimensions of socio-economic rights violations. It is sometimes asked whether the Constitutional Court's socio-economic rights jurisprudence, in general, and its turn to meaningful engagement, in particular, gets the balance right between doing justice to the individual litigants and addressing the structural impediments to the realisation of these rights in ways that go beyond the individual dispute before the court. A resort to meaningful engagement could inhibit the development of standards providing adequate guidance to lower courts and organs of state, which would allow socio-economic dis-

35 See Residents of Joe Slovo Community, note 31, para 5 for the interim order.

36 See Residents of Joe Slovo Community, note 31, para 7 for the Court's order; and paras 241 and 261 on the need for individualised engagement.

37 Residents of Joe Slovo Community, note 31, para 20. In its interim order in Mamba $v$ Minister of Social Development (CCT) unreported case no 65/08 of 21 August 2008 para 5, the Constitutional Court ordered the Gauteng provincial government to engage meaningfully with refugees and with certain civil-society organisations about its decision to close temporary refugee camps. 
advantage to be addressed in a more systemic and better coordinated manner. Danie Brand criticises the decision in Olivia Road, in which the agreement reached between the parties was made an order of court. The Court failed to create binding precedent and limited the significance of the case to the individual parties. He also notes that the Court expressly refrained from deciding the application for an order compelling the City to devise a plan for dealing with other people who lived in condemned buildings. The judgment thus focused narrowly on the individual dispute before the court, and failed to address systemic problems or engage the larger public good. ${ }^{38}$ Brian Ray, on the other hand, argues for an interpretation of Olivia Road which places structural issues at the forefront. On this reading, the judgment requires the authorities to 'develop structured, long-term approaches' which build engagement into their plans 'from the start of any redevelopment process'. ${ }^{39}$ Administrative structures (including engagement training for officials) must be developed as a means of integrating engagement processes into policy- and decision-making, and civil society organisations must be involved at various stages of the process.

This literature draws attention to the fluidity of the distinction between general and individual application. Since the resolution of a dispute about the eviction of individual households inevitably touches upon issues of a structural and collective nature, it seems problematic to restrict meaningful engagement to the immediate parties to the dispute. Given this public dimension, it could be argued that it is not only the rule of law and fundamental rights that come into play, but that the constitutional value of democracy may require an opening-up of the participatory process to allow broader public involvement. ${ }^{40}$

38 Danie Brand, The South African Constitutional Court and Livelihood Rights, in: Oscar Vilhena / Upendra Baxi / Frans Viljoen (eds.), Transformative Constitutionalism: Comparing the Apex Courts of Brazil, India and South Africa, Pretoria 2013, pp. 435-437. See also Sandra Liebenberg, Engaging the Paradoxes of the Universal and Particular in Human Rights Adjudication: The Possibilities and Pitfalls of 'Meaningful Engagement', African Human Rights Law Journal 12 (2012), p. 19 ('there is a real danger that meaningful engagement as an adjudicatory strategy may descend into an unprincipled, normatively empty process of local dispute settlement').

39 Brian Ray, Engagement's Possibilities and Limits as a Socio-Economic Rights Remedy, Washington University Global Studies Law Review 9 (2010), p. 423.

40 I am grateful to an anonymous reviewer for pointing this out. 
When would engagement qualify as 'meaningful'? In Olivia Road, the Court highlighted the need for 'structured, consistent and careful engagement' in cities in which a large number of people stand to be affected by evictions. ${ }^{41}$ It also noted that parties to the negotiations must act reasonably and in good faith. ${ }^{42}$ In Joe Slovo, Sachs J criticised the 'top-down approach' adopted by the government. In terms of this approach, the authorities reported back to the community in order to "pass on information about decisions already taken rather than to involve the residents as partners in the process of decision-making itself' ${ }^{43}$ Such an approach falls short of the deliberative form of democracy envisaged by the Court, which is characterised by mutual respect, a willingness to listen to other viewpoints and ongoing engagement between the parties. In the Court's view, the aim should be to look for solutions that are mutually acceptable, rather than simply to placate residents or to inform them of decisions already taken. Engagement is thus conceived as a partnership. However, that does not mean that the relationship between the state and the residents is completely equal. As Ngcobo J pointed out in Joe Slovo, even though the state's decision must 'be informed by the concerns raised by the residents during the process of engagement', ${ }^{44}$ the parties are not required to reach agreement on all issues:

"Mutual understanding and accommodation of each others' concerns, as opposed to reaching agreement, should be the primary focus of meaningful engagement. Ultimately, the decision lies with the government." 45

On the one hand, then, the Court's meaningful engagement jurisprudence envisages sustained deliberations between the authorities and the residents affected, which are aimed at establishing relationships of mutual accommodation and trust. On the other hand, it neither requires the government to secure the consensus of the affected residents nor allows it to cede its decision-making power to them. ${ }^{46}$ In fact, it would be unconstitutional to

41 Olivia Road, note 31, para 19.

42 Olivia Road, note 31, para 20.

43 Residents of Joe Slovo Community, note 31, para 378.

44 Residents of Joe Slovo Community, note 31, para 244.

45 Residents of Joe Slovo Community, note 31, para 244.

46 Gustav Muller, Conceptualising 'Meaningful Engagement' as a Deliberative Democratic Partnership, in: Sandra Liebenberg / Geo Quinot (eds.), Law and Poverty: Perspectives from South Africa and Beyond, Cape Town 2012, pp. 311-313 argues, with reference to Arnstein's ladder of citizen participation, that 
delegate its decision-making power to the residents, as there are others too who are affected by government decisions but who are not parties to the engagement, and whose interests must be taken into consideration. ${ }^{47}$

The judgment in Olivia Road states that whether or not meaningful engagement has occurred, is one of the circumstances a court must take into account when faced with an application for eviction. ${ }^{48}$ The expectation that meaningful engagement would become a prerequisite for eviction was, however, dashed in Joe Slovo. In that case the Court held that, despite the clear inadequacy of the engagement process, the state had acted reasonably in seeking the eviction of the occupiers. The Court condoned the authorities' failure to engage meaningfully, but in its order required engagement in relation to the details of the relocation. Liebenberg describes the judgment as 'normatively weak', as it allowed pragmatic considerations to dilute the requirements of reasonableness and reduced meaningful engagement to a remedial safeguard which had to 'ensure participation in the nuts and bolts of the implementation of the eviction order'. ${ }^{49}$

\section{Concluding remarks}

The Constitutional Court's conceptualisation of public participation in the law-making process and in eviction cases makes for an interesting comparison. Participation in the legislative process is inclusive, as it extends to a broad public. Moreover, the judgment in Doctors for Life sends out a powerful message: that in terms of the Constitution representative democracy and participatory democracy go hand in hand, and that a failure to fa-

meaningful engagement is best conceptualised as a partnership. On the one hand, this implies a greater degree of control by citizens than forms of participation characterised as manipulation, therapy, informing, consultation and placation. On the other hand, it stops short of the level of citizen power suggested by Arnstein's top two categories, namely delegated power and citizen control.

47 See the comments of O'Regan J in Residents of Joe Slovo Community, note 31, paras 293, 303.

48 Olivia Road, note 31, para 18. See also para 21, where it is stated that the absence of engagement or the municipality's failure to act reasonably in the engagement process 'would ordinarily be a weighty consideration against the grant of an ejectment order'.

49 Liebenberg, note 38, p. 23. 
cilitate reasonable participation in the legislative process must result in the invalidity of the legislation in question. The force of this message is, however, undermined by the Court's unwillingness to inquire into legislative motives or to consider the rationality of legislative procedures. Its adherence to a strict division between democracy and the rule of law thus deprives judges of the power to test whether the public's views were truly considered and weakens their capacity to challenge the ways in which unequal power relations diminish the ability of the poor and marginalised to participate.

On the other hand, an ongoing and individualised form of engagement is envisaged in the case of evictions, which is designed to establish relations of mutual understanding, accommodation and trust. Here, the Court seems more willing to question whether the authorities have negotiated in good faith and have truly listened to the inputs of residents. However, the fact that a failure to engage meaningfully is not an absolute requirement for the granting of an eviction order, undercuts the normative force of this obligation.

Such a comparison generally confirms Steiger's articulation of the (quasi-)legislative and (quasi-)judicial functions with collective and individual self-determination, respectively. In line with this model, rights of participation in the law-making process accrue to the general public, while rights of participation in the case of evictions are vested in individuals and households. However, as the above analysis shows, this general principle is subject to a number of qualifications. For instance, the adoption of Acts of Parliament, which is clearly a legislative function, sometimes has a particular impact on discrete - and often vulnerable - groups or communities, in which case respect for the dignity of those thus affected may require additional measures to enable them to participate. Moreover, the vulnerability of households about to be evicted requires the involvement of civil-society organisations, which may inject important public-interest considerations into the negotiations between the state and individual households. In addition, the Court's meaningful engagement jurisprudence raises questions over the relationship between the particularity of individual disputes and the collective and structural dimensions underlying them. Ways must be found of opening up these disputes for broader participation, and of articulating the need to do justice to the individual parties with the need to address wider systemic problems.

These qualifications not only illustrate the hybridity of exercises of public power, but also remind us of the implications of structural power 
and material disadvantage for communities and individuals' ability to access and participate in official spaces. In a society characterised by systemic forms of discrimination, private inequality tends to spill over into the public-political sphere. When this happens, wealth and privilege determine access to the means of political power, and the public interest becomes infused with the particularity of a specific set of private interests. ${ }^{50}$

On the one hand, then, the participatory turn in post-apartheid law is driven, at least in part, by the desire to overcome the distorting effects of private wealth and power on representative institutions. On the other hand, these effects are reproduced within official participatory spaces. The poor and marginalised (including women, children, the elderly and people with disabilities) tend to be at a disadvantage in these spaces - vis-à-vis organised and moneyed elites, vis-à-vis politicians' power to frame participatory spaces and determine the agenda and terms of engagement, vis-à-vis bureaucratic powers of implementation and vis-à-vis powerful voices within their own communities. ${ }^{51}$

What is thus needed is a conceptualisation of participation which can come to terms both with the hybridity of exercises of public power, and with a context of structural and material disadvantage. Such an understanding of participation must accept that the boundaries between the general and particular and between legislation and adjudication are fluid and contested. Rather than assuming that public participation programmes will afford everyone an equal opportunity to influence laws, policies and decisions, it must emphasise the need to frame participatory spaces in a way which challenges and disrupts unequal power relations and to ensure that everyone has an effective opportunity to participate, both in the formation and implementation of laws and policies.

Steiger's separation-of-powers-based conceptualisation of participation is not necessarily at odds with these premises, as it does not assume that

50 See Margaret Somers, Genealogies of Citizenship: Markets, Statelessness, and the Right to Have Rights, Cambridge 2008; Wendy Brown, Undoing the Demos: Neoliberalism's Stealth Revolution, Zone Books 2015 for different perspectives on the subjection of the public-political sphere to neoliberal economics.

51 Janine Hicks / Imraan Buccus, Crafting New Democratic Spaces: Participatory Policy-Making in KwaZulu-Natal, South Africa, Transformation 65 (2007), p. 94; Sandra Liebenberg / Katharine Young, Adjudicating Social Rights: Can Democratic Experimentalism Help?, in: Helena Aliviar García / Karl Klare / Lucy Williams (eds.), Social and Economic Rights in Theory and Practice: A Critical Assessment, New York 2014, p. 75. 
the separation of powers denotes a rigid division of state functions into watertight compartments, or that exercises of public power neatly fall on either side of the divide between individual rights and the public interest. Rather, it concerns itself with the overlaps between different state functions and seeks to provide a nuanced mechanism which is able to account for the intersections between democracy, the rule of law and fundamental rights. But something more is needed to come to terms with the hybridity of public power and the pervasiveness of structural and material disadvantage. What is needed is a better understanding of the constantly shifting relationship between the general and particular, the public and the private and collective and individual self-determination, and of its implications for democratic participation and voice. If the separation of powers principle is to serve as a context-sensitive guide to the mediation of the tensions inherent in participation, it needs to be supplemented by a robust understanding of democracy that is alive to the capacity of democratic action to challenge and disrupt the boundary between the individual and collective. ${ }^{52}$

52 See Henk Botha, The Rights of Foreigners: Dignity, Citizenship and the Right to Have Rights, South African Law Journal 130 (2013), p. 836 and the literature referred to therein on the capacity of democratic struggles to problematise the relation between public and private and between the individual and citizen. 
